\title{
Dopuszczalna wielkość szczeliny w złączu spawanym ze względu na możliwość jego pękania
}

\author{
The permissible size of the fissure in welded joint \\ because of the possibility of his cracking
}

\section{Streszczenie}

Praca przedstawia ocenę złącza spawanego zawierającego niezgodność $w$ postaci szczeliny ze względu na możliwość jego pękania. Obliczono dopuszczalną wielkość szczeliny wskrośnej w złączu spawanym oraz określono stan bezpieczeństwa dla złącza zawierającego niezgodność odkrytą - szczelinę półeliptyczną o założonych wymiarach. Obliczenia wykonano na podstawie krytycznych właściwości materiału złącza dla dwóch poziomów obciążenia rozciągającego z uwzględnieniem przyjętego modelu rozkładu naprężęń własnych w złączu. Krytyczne właściwości materiału, tj. krytyczne rozwarcie czoła pęknięcia i odporność na pękanie, wyznaczono na podstawie wyników badań udarności dla każdej strefy złącza.

Słowa kluczowe: złącza spawane; kruche pękanie; niezgodności złączy spawanych

\begin{abstract}
The work presents the opinion of welded joint with the defect, i.e. fissure, because of the possibility of his cracking. The permissible size of the fissure thoroughly in welded joint was calculation and the state of the safety was qualified for welded joint including the open defect - semielliptical fissure for put her dimensions. The calculations were made on the basis of the critical material proprieties of welded joint for two levels of tensile loading with the regard put model of the residual stress distribution. The critical material proprieties, i.e.: fracture toughness and the critical crack tip opening displacement, were estimated on basis of the test results of impact resistance for every zone of the welded joints.
\end{abstract}

Keywords: welded joints; fragile cracking; welded joints' incompatibilities

\section{Wstęp}

Ocena złącza spawanego zawierającego niezgodności spawalnicze (wady) w postaci szczelin sprowadza się do wyznaczania krytycznej lub dopuszczalnej ich wielkości lub do określenia stanu bezpieczeństwa złącza zawierającego szczelinę o znanej wielkości. Taka ocena złącza jest niezbędna ze względu na możliwość jego nagłego pękania. Oparta ona jest jest na zasadach liniowo-sprężystej mechaniki pękania (LSMP), według której kruche pęknięcie elementu ze szczeliną wystąpi gdy się współczynnik intensywności naprężenia $K_{1}$ na czole szczeliny osiągnie wartość krytyczną $\mathrm{K}_{\mathrm{Ic}}\left(\mathrm{K}_{\mathrm{I}}=\mathrm{K}_{\mathrm{Ic}}\right)[1,2]$. Kruche pękanie, występuje zwykle w płaskim stanie odkształcenia w elementach grubych przy niskim poziomie obciążenia, tj. gdy naprężenie nominalne względem granicy plastyczności jest niewielkie $(\sigma / R e \leq 0,5)$. Strefa plastyczna na czole szczeliny jest wtedy bardzo mała i można ją pominąć [2,3]. Jednak kryterium LSMP można też stosować przy wyższym poziomie naprężenia, tzn. dla $05<\sigma / R_{e} \leq 0,8$, gdzie rozpatruje się efektywną wielkość szczeliny $a_{\text {ef. }}$. Jest ona sumą rzeczywistej wielkości szczeliny a i strefy plastycznej na jej czole $-r_{p}\left(a_{e f}=a+r_{p}\right)[2,3]$.

W elementach o małej grubości przy wyższych poziomach obciążenia $\left(\sigma / R_{e}>0,5\right)$ na czole szczeliny tworzy się większa strefa plastyczna. O możliwości pękania materiału $\mathrm{w}$ tym stanie decyduje wielkość rozwarcia czoła szczeliny $\bar{\delta}_{a}$, która po osiągnięciu krytycznej wartości $\delta_{c}\left(\delta_{a}=\delta_{c}\right)$ powoduje quasi-kruche pękanie materiału, zgodnie z założeniami sprężysto-plastycznej mechaniki pękania (SPMP) [1 $\div 4]$. Obecność szczelin nawet o bardzo małych wymiarach w elementach konstrukcyjnych poddanych działaniu obciążeń zmiennych może zainicjować rozwój pęknięcia zmęczeniowego, którego wzrost do wartości krytycznej (po pewnej liczbie cykli obciążenia) prowadzi także do zniszczenia elementu. W takim przy-

Dr hab. inż. Krzysztof Werner, prof. PCz; dr inż. Kwiryn Wojsyk - Politechnika Częstochowska.

Autor korespondencyjny/Corresponding author: krzysztofwerner@tlen.pl 
padku można określić trwałość zmęczeniową elementu na podstawie wyników badania rozwoju pęknięć w złączach spawanych $[5,6]$.

Współczynnik intensywności naprężenia w złączu spawanym zależy od wielkości naprężeń nominalnych spowodowanych obciążeniem zewnętrznym oraz naprężeń własnych, których rozkład i wartość można określić za pomocą analiz numerycznych (np. metodą elementów skończonych [7]) albo za pomocą różnych metod pomiaru lub modeli obliczeniowych [3].

Wielkości i kształty niezgodności spawalniczych, widoczne na przełomach próbek łamanych udarowo [8], można wykryć i zmierzyć za pomocą badań nieniszczących, np. badań ultradźwiękowych lub radiograficznych.

Obliczenia wytrzymałościowe złączy spawanych dla obciążeń statycznych i zmiennych wg Eurokodu 3 omówione są np. w pracach $[9,10]$. Jednak możliwość zastosowania tej metodyki obliczeń przez inżynierów spawalników jest mało rozpoznana. Dlatego niniejsza praca przedstawia metodykę i wyniki obliczeń dla najczęściej spotykanych szczelin w złączach spawanych z uwzględnieniem własnych naprężeń spawalniczych. Zilustrowano to na przykładzie wyznaczenia długości dopuszczalnej niezgodności wzdłużnej, tj. szczeliny wskrośnej oraz określenia stanu bezpieczeństwa złącza zawierającego odkrytą wadę wzdłużną, tj. szczelinę półeliptyczną o znanych wymiarach. Tematyka pracy jest szczegółowym omówieniem ogólnego zagadnienia związanego z oceną zagrożenia pękaniem złączy spawanych, prezentowanego przez autorów tej publikacji w pracach $[11,12]$.

\section{Ocena możliwości pękania złącza spawanego zawierającego szczelinę}

Dopuszczalny wymiar a wzdłużnej symetrycznej szczeliny wskrośnej o łącznej długości 2a oraz stan bezpieczeństwa złącza z wzdłużną szczeliną odkrytą - półeliptyczną o głębokości a i długości 2c na jego powierzchni określono dla doczołowo spawanych złączy ze spoiną "V" o kącie rozwarcia rowka $60^{\circ}$. Złącza wykonano z blach stali o podwyższonej wytrzymałości S355J2+N w stanie po normalizowaniu $[13,14]$. Blachy o grubości $\mathrm{g}=12 \mathrm{~mm}$ spawano w pozycji pionowej PF (arkusz blachy o granicy plastyczności $R_{e}=384 \mathrm{MPa}$, i wytrzymałości na rozciąganie $R_{m}=574 \mathrm{MPa}$ ) oraz $\mathrm{w}$ pozycji podolnej PA (arkusz blachy o właściwościach mechanicznych: $R_{e}=435 \mathrm{MPa}$ i $R_{m}=525 \mathrm{MPa}$ ). Spoiny wykonano metodą MAG (135). Do spawania zastosowano materiał dodatkowy G3Si1 - drut o średnicy $\mathrm{d}=1,2 \mathrm{~mm}$, którego właściwości mechaniczne wynosiły: $R_{e}(s)=450 \mathrm{MPa}$ i $R_{m}(s)=545 \mathrm{MPa}$. Ścieg graniowy wykonano z podpawaniem (bez podkładki). Zgłady makroskopowe złączy spawanych w podanych pozycjach przedstawia rysunek 1 .

Rozkład naprężeń własnych i ich wielkości w spoinie i poza nią oszacowano według europejskiej procedury FITNET, zgodnie $z$ modelem podanym $w$ pracy [3]. Według tego modelu własne naprężenia poprzeczne $\sigma_{\mathrm{rt}}$ na powierzchni złącza w spoinie są równe granicy plastyczności $R_{e}$ materiału rodzimego, a w strefie wpływu ciepła (SWC) i dalej w materiale rodzimym maleją liniowo do zera na odcinku równym podwójnej grubości blachy. Na rysunku 2 przedstawiono schemat złącza spawanego ze szczeliną wskrośną o długości 2a, oznaczenie szerokości lica i grani spoiny oraz rozkład własnych naprężeń poprzecznych na powierzchni złącza.

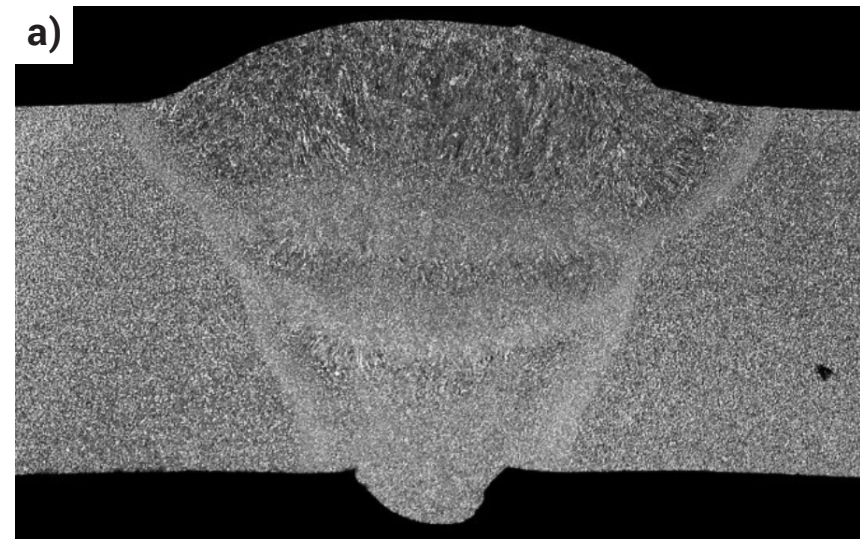

b)

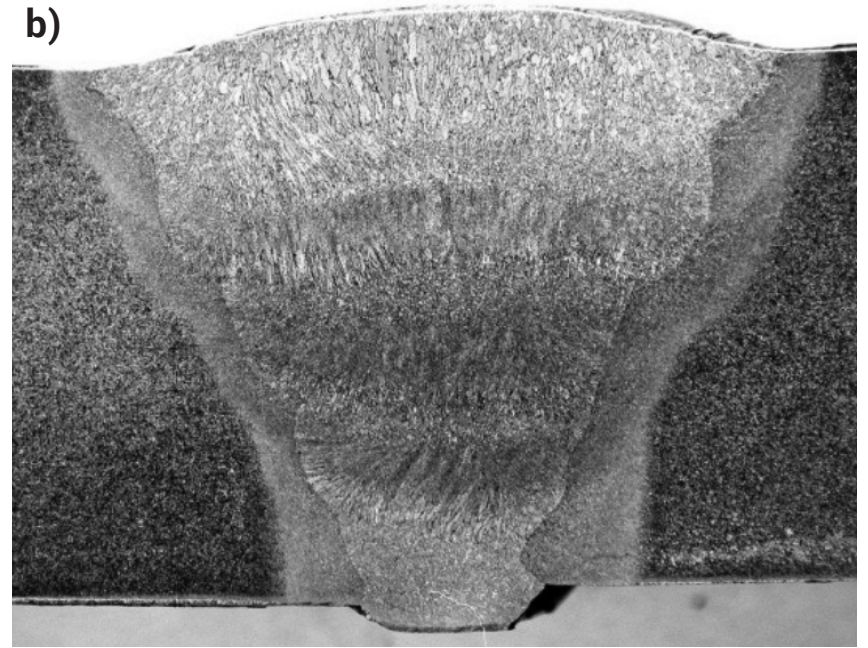

Rys. 1. Zgład makroskopowy złącza spawanego: a) w pozycji PA b) w pozycji PF

Fig. 1. The macroscopic section of welded joint: a) in the fix PA b) in the fix PF

a)

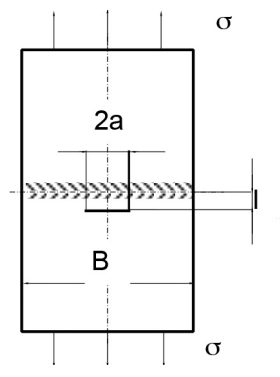

b)

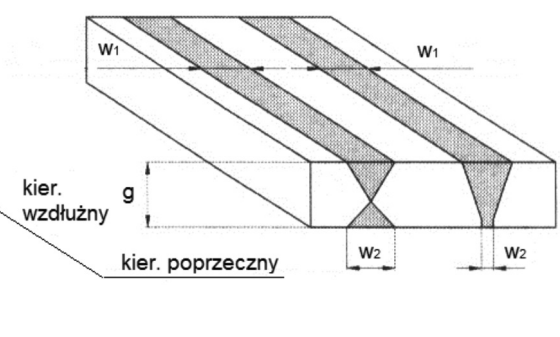

c)

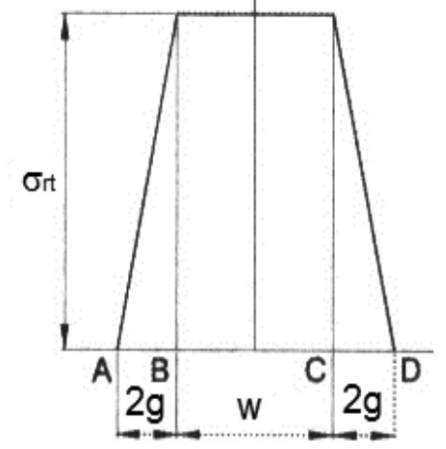

Rys. 2. Złącze spawane - schemat: a) usytuowanie szczeliny, b) model spoiny ( $w=w_{1}-$ lico; $w=w_{2}-$ grań), $c$ ) model rozkładu naprężeń własnych na powierzchni złącza [3]

Fig. 2. The scheme of welding joint: a) location of the fissure, b) model of welded joint ( $w=w_{1}-$ face; $w=w_{2}-$ edge), $c$ ) model of residual stress distribution on surface of welded joint [3] 
Właściwości charakteryzujące odporność materiału na pękanie wyznaczono dla różnych stref złącza na podstawie wyników badań udarności zawartych w pracach $[13,14]$. Wartości krytyczne: rozwarcia pęknięcia $\delta_{c}(w \mathrm{~mm})$ i odporności na pękanie $K_{\mathrm{Ic}}$ wyznaczono na podstawie pracy KV udarowego łamania próbek (wyrażonej W J) dla każdej strefy złącza $w$ temperaturze $20^{\circ} \mathrm{C}$ zgodnie z następującymi zależnościami $[2,3,11]$ :

$$
\begin{aligned}
& \delta_{c}=0,0024 \cdot(K V) \\
& K_{I c}=\sqrt{R_{e} \cdot \delta_{c} \cdot E}
\end{aligned}
$$

Wyniki badań KV (J) oraz obliczeń wartości krytycznych $\delta_{c}$ i $K_{\mathrm{Ic}}$ dla różnych stref złącza ze spoiną spawaną w pozycji PF podano $\mathrm{w}$ tablicy l, w pracy [11] oraz $\mathrm{w}$ pracy [13]. Wartości średnie pracy udarowego łamania złączy ze spoiną wykonaną w pozycji PA, wyznaczone na podstawie wyników badań zawartych w pracy [14], podano przykładowo w tablicy I.

Tablica I. Praca udarowego łamania - wartości średnie z 3 próbek o przekroju w karbie $10 \times 8 \mathrm{~mm}$

Table I. The work of stroke break - average values of tree samples on cross-section in noth $10 \times 8 \mathrm{~mm}$

\begin{tabular}{|c|c|c|c|c|}
\hline $\begin{array}{c}\text { Strefa } \\
\text { złącza }\end{array}$ & Lico & Grań & SWC & $\begin{array}{r}\text { Mat. } \\
\text { Rodz. }\end{array}$ \\
\hline $\mathrm{KV}, \mathrm{J}$ & 158 & 149 & 152 & 149 \\
\hline
\end{tabular}

Do określeneia możliwości pękania złącza spawanego zawierającego szczelinę zastosowano kryterium LSMP. Wyznaczono wielkość dopuszczalnej szczeliny $a_{d}$, z zastosowaniem współczynnika bezpieczeństwa $\mathrm{b}=2$ [2]. Na podstawie pierwszego wariantu (poziomu) oceny wstępnej, definiuje się maksymalną wartość parametru odporności materiału na pękanie $K_{r}$ jako kryterium pękania:

$$
K_{r}=K_{I} / K_{I c}=\sqrt{2} / 2
$$

Ten poziom oceny obowiązuje dla obciążenia zewnętrznego rozciągającego $S_{r}=\sigma_{r} / \sigma_{f} \leq S_{r f}=0,8$. Naprężenie końcowe $\sigma_{f}$ określa się jako: $\sigma_{f}=0,5$ $\left(R_{e}+R_{m}\right) \leq 1,2 R_{e}$ [3]. Ocenę możliwości pękania złączy spawanych badanej stali, zawierających niezgodność w postaci szczeliny przeprowadzono dla dwóch poziomów obciążenia zewnętrznego $\sigma_{\mathrm{r}}=0,5 \mathrm{R}_{\mathrm{e}}$ oraz $\sigma_{\mathrm{r}}=0,8 \mathrm{R}_{\mathrm{e}}$ w każdej strefie złącza. W obliczeniach uwzględniono naprężenie rozciągające od obciążenia nominalnego wraz z naprężeniami własnymi wg założonego modelu, tj. w spoinie na poziomie granicy plastyczności materiału rodzimego, a poza spoiną - średnie naprężenie własne z obu powierzchni złącza. Uwzględniono także różne wartości granicy plastyczności $R_{e}$ materiału rodzimego i spoiny, a w SWC wartość wynikającą z liniowej zmiany $\mathrm{R}_{\mathrm{e}}$.

\section{Dopuszczalna wielkość wzdłużnej szczeliny wskrośnej}

Długości dopuszczalnej szczeliny wskrośnej $a=a_{d}$ w złączu o szerokości B wyznaczono z równania (3) dla naprężenia $\sigma$ i założonego stosunku B/a we współczynniku korekcyjnym Y. Współczynnik intensywności naprężenia określono jako:

$$
K_{I}=\sigma \cdot Y \sqrt{\pi \cdot a}
$$

gdzie:

$$
Y=\sqrt{\frac{B}{\pi \cdot a} \operatorname{tg} \frac{\pi \cdot a}{B}}
$$

Stąd po przekształceniu równania (3) dopuszczalna długość szczeliny wskrośnej wynosi:

$$
a_{d}=\frac{K_{I c}^{2}}{2 \cdot(\sigma \cdot Y)^{2} \cdot \pi}
$$

Dodatkowo, zgodnie z innym kryterum LSMP uwzględniającym odkształcenie plastyczne na czole pęknięcia [2], wyznaczono też długość centralnej, równoważnej szczeliny wskrośnej $a_{m}$ :

$$
a_{m}=C\left(K_{I c} / R_{e}\right)^{2}
$$

gdzie współczynnik $C$ obowiązujący dla $\sigma / R_{e} \geq 0,5$ jest równy.

$$
C=\frac{1}{2 \pi\left[\left(\sigma / R_{e}\right)-0,25\right]}
$$

\section{Ocena możliwości pękania złącza z wzdłużną szczeliną odkrytą półeliptyczną}

Do oceny możliwości pękania złącza z wzdłużną szczeliną odkrytą - półeliptyczną o założonych wymiarach a i 2c zastosowano bezpośrednio kryterium stanu bezpieczeństwa wg wzoru (3) obowiązującego dla poziomu obciążenia zewnętrznego $S_{r} \leq 0,8$.

Złącze ze szczeliną poddane działaniu stałego obciążenia nie jest narażone na pęknięcie gdy jego parametr odporności na pękanie $\mathrm{K}_{\mathrm{r}}$ i poziom stanu obciążenia $S_{r}$ nie przekroczą wartości granicznych $\left(K_{r}=\sqrt{ } 2 / 2\right.$ i $\left.S_{r}=0,8\right)$. Obliczenia parametru $K_{r}$ wykonano wg wzoru (3) dla współczynnika intensywności naprężenia $K_{\text {I }}$ określonego jako:

$$
K_{I}=\sigma \frac{M_{m}}{\phi} \sqrt{\pi \cdot a}
$$




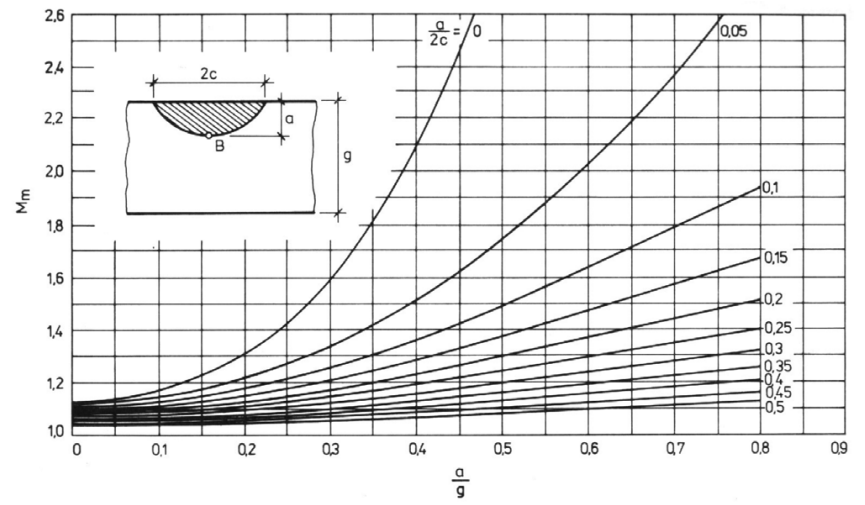

Rys. 3. Współczynnik Mm w punkcie B szczeliny półeliptycznej [2] Fig. 3. The coefficient $\mathrm{Mm}$ in point $\mathrm{B}$ of the semielliptical fissure [2]

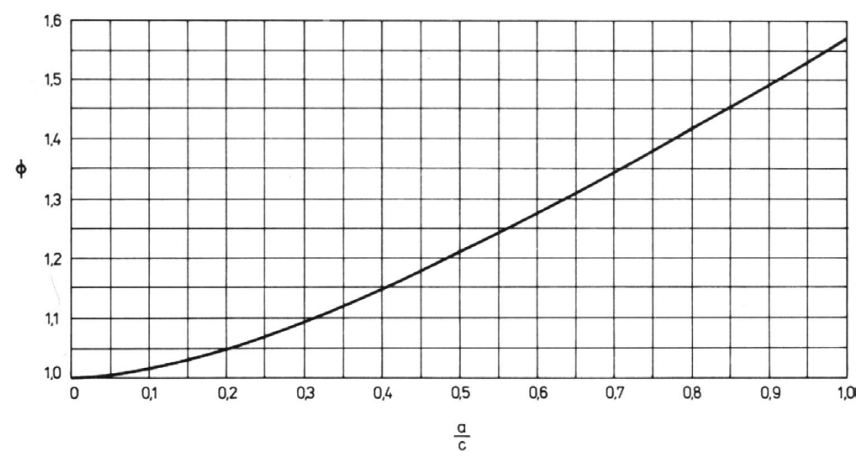

Rys. 4. Wartość całki eliptycznej dla szczeliny półeliptycznej i eliptycznej

Fig. 4. Value of the elliptic integral for semielliptical and elliptical fissure [2]

Współczynnik korekcyjny $M_{m}$ w punkcie B szczeliny półeliptycznej można określić z wykresu przedstawionego na rysunku 3, w zależności od stosunków wymiarów: a/g i a/2c. Natomiast wartość całki eliptycznej $\varphi$ zależnej od stosunku wymiarów a/c można określić z wykresu przedstawionego na rysunku 4 [2].

\section{Wyznaczone, bezpieczne długości szczelin wskrośnych w rozpatrywanych złączach}

Obliczone dopuszczalne i równoważne długości szczeliny wskrośnej w funkcji jej położenia w złączu spawanym przedstawiono na rysunkach 5 i 6 dla złączy ze spoiną wykonaną w pozycji PF oraz na rysunkach 7 i 8 dla złączy ze spoiną wykonaną w pozycji PA.

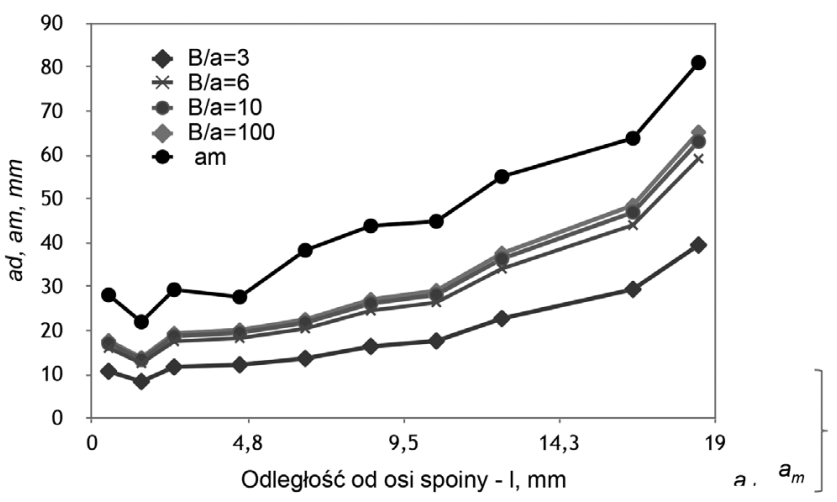

Rys. 5. Długość szczeliny: dopuszczalna $a_{d}(w z .5)$ oraz równoważna $a_{m}$ (wz. 6). Spoina wykonana w pozycji $P F, \sigma_{r}=0,5 R_{e}$

Fig. 5. The length of fissure: permissible $a_{d}$ (formula 5 ) and equivalent $a_{m}$ (formula 6). The joint welded in the fix PF, $\sigma_{r}=0,5 R_{e}$

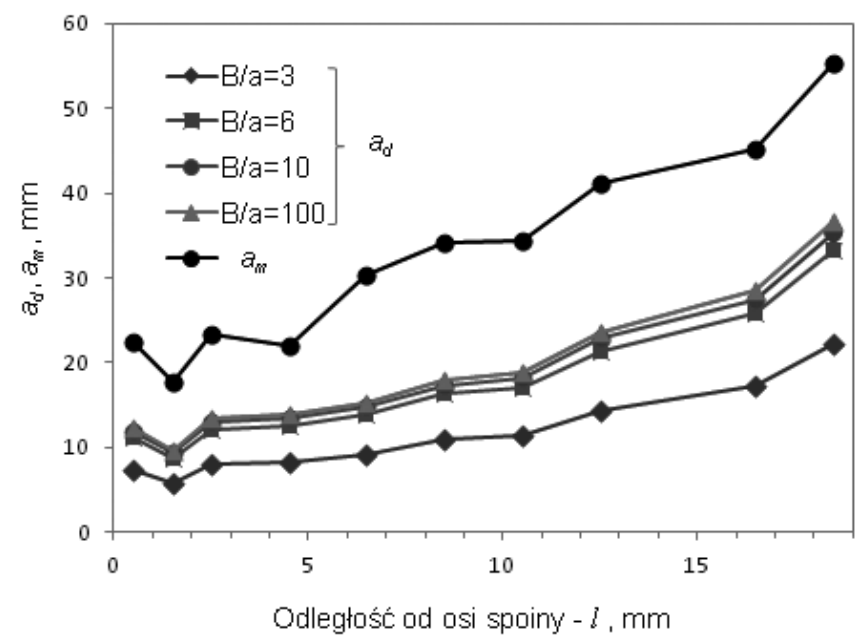

Rys. 6. Długość szczeliny: dopuszczalna $a_{d}(w z .5)$ oraz równoważna $a_{m}$ (wz. 6). Spoina wykonana w pozycji $P F, \sigma_{r}=0,8 R_{e}$

Fig. 6. The length of fissure: permissible $a_{d}$ (formula 5 ) and equivalent $a_{m}$ (formula 6). The joint welded in the fix $P F, \sigma_{r}=0,8 R_{e}$

Wyznaczone długości dopuszczalne $a_{d}$ szczeliny wskrośnej wg wzoru (5) na podstawie badania udarności 10 złączy o różnym położeniu szczeliny względem spoiny wykonanej w pozycji PF są najniższe $w$ spoinie i wraz ze wzrostem odległości I od niej wzrastają, początkowo nieznacznie W SWC, a następnie coraz szybciej osiągając ponad trzykrotnie większe wartości przy większej odległościach I. Tendencja ta dotyczy zarówno niskiego poziomu obciążenia (rys. 3), jak i wysokiego (rys. 4). Jednak przy wyższym poziomie obciążenia długości szczeliny dopuszczalnej są znacząco mniejsze. Podobne tendencje zmiany dotyczą długości szczeliny równoważnej $\mathrm{a}_{\mathrm{m}}$ dla obu poziomów obciążenia. Jednak wyznaczone wartości $a_{m}$ są wyraźnie większe niż odpowiadające im wartości $a_{d}$.

Istotny wpływ na wartość długości szczeliny dopuszczalnej ma stosunek szerokości złącza do długości szczeliny $B / a$. Przy małej wartości $B / a=3$ długości szczeliny dopuszczalnej ad są rzędu ok. $60 \%$ odpowiednich długości $a_{d}$ dla złącza o wartości $B / a=10$. Wraz ze wzrostem względnej szerokości złącza wpływ ten maleje $\mathrm{i} n \mathrm{n}$. dla $\mathrm{B} / \mathrm{a}=100$ wartości $\mathrm{a}_{\mathrm{d}}$ są tylko nieznacznie większe niż dla $\mathrm{B} / \mathrm{a}=10$.

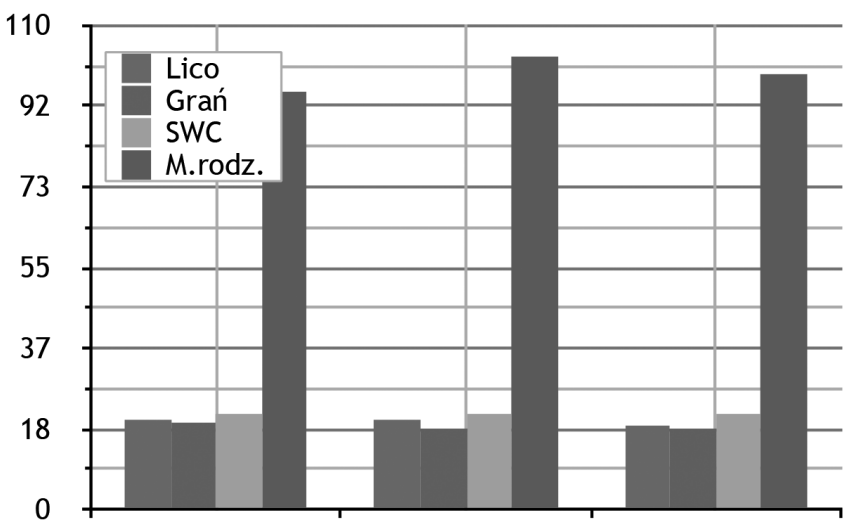

Rys. 7. Długość szczeliny równoważnej $a_{m}, m m$ (wz. 6) przy $\sigma_{r}=0,5 R_{e}$ dla trzech serii próbek pobranych $w$ różnych strefach złącza ze spoiną spawaną w pozycji PA

Fig. 7. The length of equivalent fissure $a_{m}, m m$ (formula 6) at $\sigma_{\mathrm{r}}=0,5 R_{\mathrm{e}}$ for three series of samples in the fix PA taken in various zones of welded joint 
a)

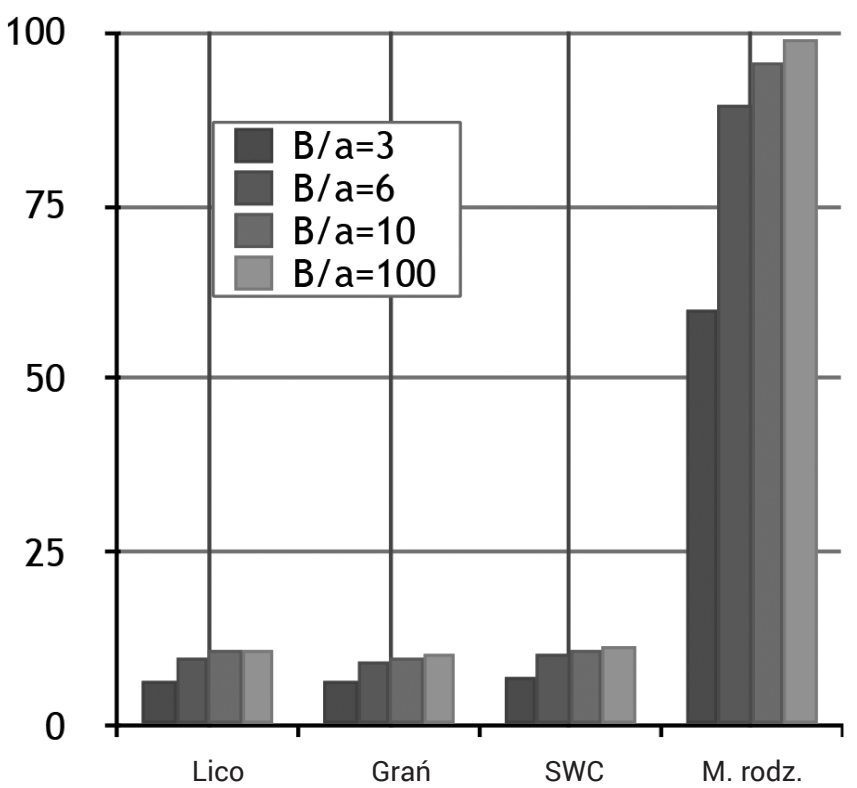

b)

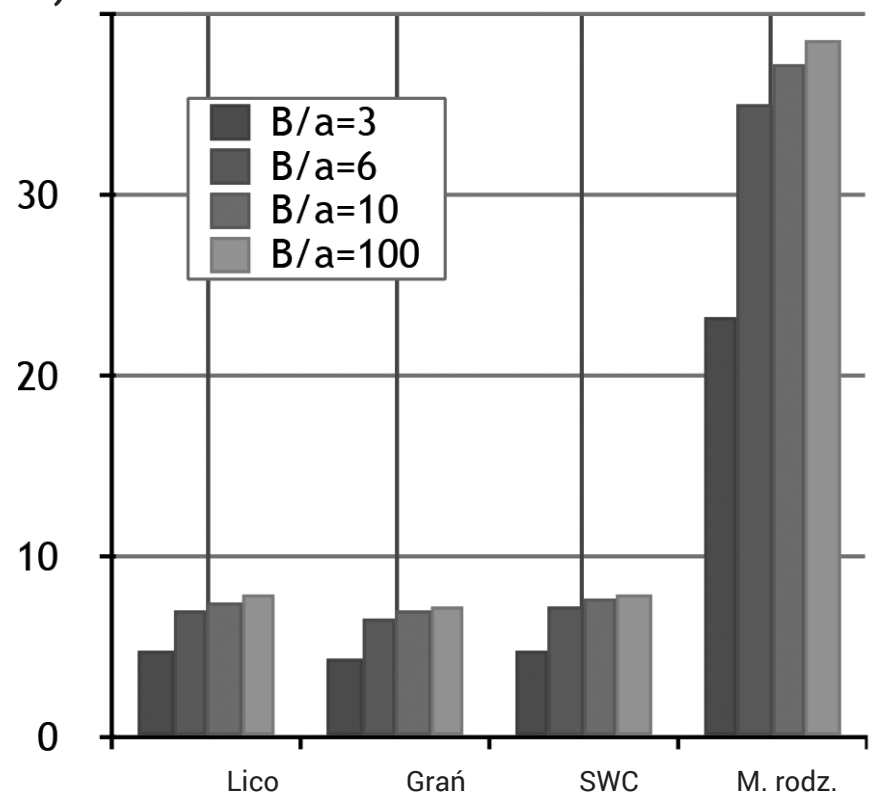

Rys. 8. Długość szczeliny dopuszczalnej $a_{d}, m m$ (wz. 5 - wartości średnie) dla $\sigma_{r}=0,5 R_{e}(a)$ i or $=0,8 R_{e}(b)$. Złącza ze spoiną spawaną w pozycji PA o różnej szerokości względnej (B/a)

Fig. 8. The length of permissible fissure $a_{d}$ (formula 5 - average values) for $\sigma_{r}=0,5 R_{e}(a)$ and $\sigma r=0,8 R_{e}(b)$. The welded joints with joint in the fix PA for the various relative width

Obliczone długości szczelin $a_{m}$ (rys. 7) na podstawie wyników badań udarności trzech próbek w każdej strefie złącza ze spoiną spawaną w pozycji PA wykazywały bardzo małe różnice (podobnie jak długości $a_{d}$ ). Ich wartości były małe i zbliżone do siebie w strefie lica i grani spoiny oraz w SWC. Natomiast w materiale rodzimym były około cztery razy większe niż w wymienionych strefach spoiny. Wartości średnie długości dopuszczalnego pęknięcia $a_{d}$ dla strefy grani oraz SWC (rys. 8a) są o około połowę mniejsze niż długości równoważnego pęknięcia am w tych strefach (rys. 7). W strefie lica spoiny (rys. 8) wartości $a_{d}$ są najmniejsze, co może wskazywać na większą skłonność do kruchego pękania spoiny spawanej w pozycji PA niż w pozycji PF. Wynikać to może z większego wpływu samoczynnej obróbki cieplnej spoiny wykonanej w pozycji PF na rozdrobnienie ziarna (większa liczba ściegów) niż w pozycji PA. Natomiast $w$ materiale rodzimym wartości $a_{m}$ oraz $a_{d}$ dla szerokich złączy $(B / a \geq 10)$ są prawie jednakowe, co można zaobserwować porównując odpowiednie wykresy na rysunkach 7 i 8 . Przy wysokim poziomie obciążenia $\left(\sigma_{\mathrm{r}}=0,8 \mathrm{R}_{\mathrm{e}}\right)$ długości $\mathrm{a}_{\mathrm{d}}$ dopuszczalnego pęknięcia dla każdej strefy złącza są mniejsze niż przy niskim $\left(\sigma_{r}=0,5 R_{e}\right)$, co wynika $z$ analizy ich wartości przedstawionych na rysunkach: $8 \mathrm{a}$ i $8 \mathrm{~b}$.

Istnienie niezgodności spawalniczej odkrytej w postaci szczeliny półeliptycznej w złączu spawanym jest mniej niebezpieczne niż szczeliny wskrośnej. Zagrożenie możliwością pękania (rys. 9) pojawia się przy większych wymiarach szczeliny $(a / c=6 / 30 \mathrm{~mm})$ i stosunkowo wysokim poziomie obciążenia $\left(\sigma_{\mathrm{r}}=0,8 \mathrm{Re}\right.$, tzn. $\left.S_{\mathrm{r}}=727\right)$ w licu spoiny, w grani i w SWC. Natomiast szczelina tej wielkości w materiale rodzimym przy tym samym poziomie obciążenia mieści się $\mathrm{w}$ polu bezpieczeństwa $\mathrm{K}_{\mathrm{r}} \times \mathrm{S}_{\mathrm{rf}}$ $=0,71 \times 0,8$ (rys. 9).

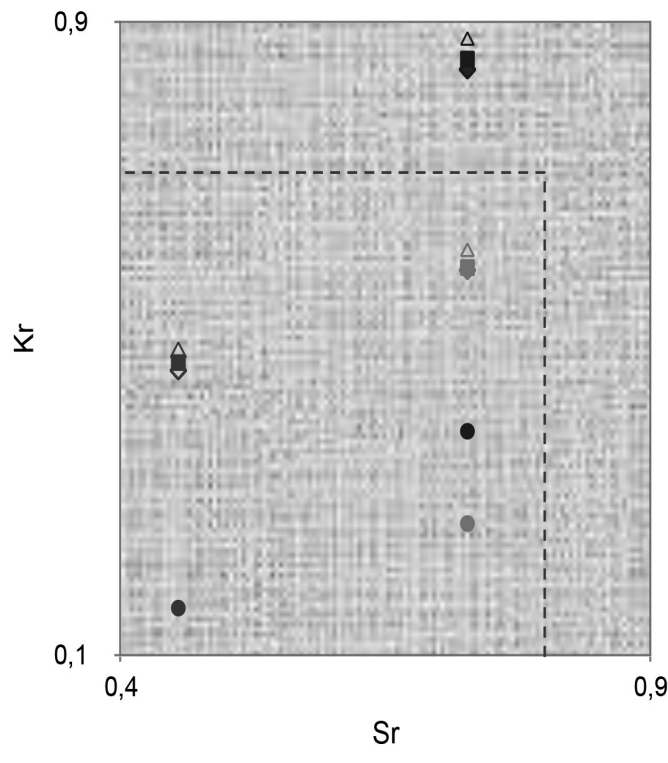

\begin{tabular}{|l|}
\hline- Pole bezp. - Kr $\times$ Srf \\
Lico $a / c=3,6 / 18$ \\
Lico $a / c=3,6 / 36$ \\
Lico $a / c=6 / 30$ \\
$\Delta$ Grań $a / c=3,6 / 18$ \\
$\Delta$ Grań $a / c=3,6 / 36$ \\
$\Delta$ Grań $a / c=6 / 30$ \\
$\diamond$ SWC $a / c=3,6 / 18$ \\
SWC $a / c=3,6 / 36$ \\
SWC $a / c=6 / 30$ \\
M.rodz. $a / c=3,6 / 18$ \\
M.rodz. $a / c=3,6 / 36$ \\
- M.rodz. $a / c=6 / 30$ \\
\hline
\end{tabular}




\section{Podsumowanie i wnioski}

Na podstawie przeprowadzonej analizy wyznaczonych dopuszczalnych wielkości wzdłużnej szczeliny wskrośnej oraz stanu bezpieczeństwa dla szczeliny połeliptycznej w doczołowym złączu spawanym sformułowano następujące spostrzeżenia i wnioski:

Wyznaczone dla różnych stref złącza spawanego długości szczeliny dopuszczalnej ad wg wzoru (5) uwzględniającego naprężenia rzeczywiste (czyli naprężenia nominalne i własne) wskazują, że największe zagrożenie pękaniem występuje w strefie spoiny i w SWC, gdzie długości ad są najmniejsze. Wraz z oddalaniem się położenia szczeliny od osi spoiny jej dopuszczalna długość wzrasta osiągając największą wartość w materiale rodzimym (ok. 4 razy większą niż w spoinie - dla złączy ze spoiną wykonaną w pozycji PA).

Istotny wpływ na wartość długości szczeliny dopuszczalnej $a_{d}$ ma stosunek szerokości złącza do długości szczeliny $\mathrm{B} / \mathrm{a}$. Przy małej wartości $\mathrm{B} / \mathrm{a}=3$ długości $\mathrm{a}_{\mathrm{d}}$ szczeliny dopuszczalnej wynoszą ok. $60 \%$ odpowiednich wartości $\mathrm{a}_{\mathrm{d}}$ dla $B / a=10$. Ogólnie, ze wzrostem względnej szerokości złącza wpływ ten szybko maleje.

Zastosowanie zależności (6) do wyznaczania długości $a_{m}$ wskrośnej szczeliny równoważnej, przy naprężeniu rzeczywistym (z uwzględnieniem naprężeń własnych), pozwala uzyskać dobrą korelację wyników długości szczeliny równoważnej i dopuszczalnej określanej wg formuły (5) ale na wyraźnie wyższym poziomie bezpiecznych długości szczeliny. Wyraźne zmiany wyznaczanych wielkości wg obu formuł występują w pobliżu granicy spoiny i SWC.

Zagrożenie możliwością pękania złącza ze szczeliną odkrytą półeliptyczną pojawia się przy większych wymiarach szczeliny $(a / c=6 / 30 \mathrm{~mm})$ i stosunkowo wysokim poziomie obciążenia $\left(\sigma_{r}=0,8 R_{e}, t z n . S_{r}=727\right)$ w licu spoiny, w grani i w SWC. Natomiast szczelina tej wielkości w materiale rodzimym przy tym samym poziomie obciążenia mieści się w polu bezpieczeństwa $\mathrm{K}_{\mathrm{r}} \times \mathrm{S}_{\mathrm{rf}}=0,71 \times 0,8$.

\section{Literatura}

[1] Kocańda S.: Zmęczeniowe pękanie metali, WNT Warszawa 198.

[2] Rykaluk K.: Pęknięcia w konstrukcjach stalowych, Dolnośląskie Wydawnictwo Edukacyjne Wrocław 2000.

[3] Neimitz A.: Mechanika pękania, PWN Warszawa 1998.

[4] Brózda J.: Wprowadzenie do mechaniki pękania, Instytut Spawalnictwa Gliwice 2008

[5] Prażmowski M., Rozumek D.: Rozwój pęknięć przy cyklicznym zginaniu w złączu cyrkon-stal powstałych w wyniku zgrzewania wybuchowego. Przegląd Spawalnictwa 4/2014 s. 45-50.

[6] Bański R., Rozumek D.: Rozwój pęknięć zmęczeniowych w bimetalach stal-tytan wykonanych metodą zgrzewania wybuchowego (platerowania). Przegląd Spawalnictwa 4/2012 s. 9.

[7] Stasiuk P., Karolczuk A., Kuczko W.: Rozkład naprężeń w krzyżowym złączu spawanym z uwzględnieniem rzeczywistego kształtu spoiny. Przegląd Spawalnictwa 1/2014 s. 29-33.

[8] Słania J., Staniszewski K., Hyc K.: Ocena przełomów złączy spawanych po próbie łamania. Przegląd Spawalnictwa 12/2013 s. 142-151.
[9] Wichtowski B.: Obliczenia złączy spawanych poddanych obciążeniom statycznym i zmęczeniowym według Eurokodu 3. Przegląd Spawalnictwa $1 / 2011$ s. 15

[10] Wichtowski B., Wichtowski M.: Wytrzymałość zmęczeniowa spoin czołowych z nakładkami wg Eurokodu 3. Przegląd Spawalnictwa 3/2011 s. 36.

[11] Werner K., Wojsyk K.: Analiza możliwości kruchego pękania spawanych elementów konstrukcji stalowych. Przegląd Spawalnictwa 5/2015 s. 91-93.

[12] Werner K., Wojsyk K.: Wyznaczanie dopuszczalnej wielkości szczeliny w złączu spawanym ze względu na możliwość jego pękania. Przegląd Spawalnictwa 10/2015 s. 45-48.

[13] Miśta J.: Ocena dopuszczalności niezgodności spawalniczych dokonywana na podstawie mechaniki pękania w złączach ze stali typu S355 w różnych temperaturach. Praca magisterska pod kier. K. Wojsyka, Częstochowa 2013.

[14] Pietrzak E.: Wyznaczanie maksymalnych niezgodności spawalniczych na podstawie zbadanych właściwości fizycznych materiału oraz mechaniki pękania. Praca magisterska pod kier. K. Wojsyka, Częstochowa 2012. 